\title{
Physical and Physiological Quality of Safflower Seed Stored in Different Packages and Temperatures
}

\author{
Aguinaldo Antonio Claudio ${ }^{1}$, Analy Castilho Polizel $^{1}$, Edna Maria Bonfim-Silva ${ }^{1}$, Niedja Marizze Cezar Alves ${ }^{1}$, \\ Tonny José Araújo da Silva ${ }^{1} \&$ Ana Paula Alves Barreto Damasceno ${ }^{1}$ \\ ${ }^{1}$ Institute of Agrarian and Technological Sciences, Federal University of Mato Grosso, Rondonópolis, Brazil \\ Correspondence: Edna Maria Bonfim-Silva, Institute of Agrarian and Technological Sciences, Federal \\ University of Mato Grosso, Rondonópolis, Brazil. Tel: 55-66-981-323-814. E-mail: embonfim@hotmail.com
}

Received: September 23, 2018

Accepted: November 15, $2018 \quad$ Online Published: January 15, 2019

doi:10.5539/jas.v11n2p330

URL: https://doi.org/10.5539/jas.v11n2p330

\begin{abstract}
Seed storage is one of the oldest techniques that, besides protecting against attacks of microorganisms and insects, has as main goal to preserve the product, with minimum losses, ensuring vigor and viability of the seeds. Safflower (Carthamus tinctorium L.) is a crop with great agricultural potential due to the high content of oil in its seed and can be a viable alternative in the production of biofuel. The goal of this study was to evaluate the effects of packaging and storage temperatures on the physical and physiological quality of safflower seeds. The experiment was conducted in the soil and plant production and bromatology laboratories of the Institute of Agrarian and Technological Sciences, Federal University of Mato Grosso Campus of Rondonópolis, in the period of July to September 2014. The experiment was a completely randomized design in a $5 \times 2$ factorial scheme, corresponding to five temperatures $\left(10,15,20,25\right.$ and $\left.30^{\circ} \mathrm{C}\right)$ and two packages (cotton and paper) with five replicates. The physical quality parameters (water content in the seed, mass of one thousand seeds, hectolitre weight) and physiological parameters (percent germination, Seed viability (Tetrazolium), accelerated aging and electric conductivity) of the seeds were evaluated. The physical quality of the safflower seed was not influenced by, the types of packaging and storage temperature. The physiological parameters of safflower seeds were significantly altered by the the type of containers and storage temperatures conditions. The paper packaging, at temperatures of 20 and $25^{\circ} \mathrm{C}$, provided greater conservation of the seed.
\end{abstract}

Keywords: Carthamus tinctorium, culture for biodiesel, germination, moisture

\section{Introduction}

One of humanity's greatest challenges is to discover new readily available alternative energy sources that result in lower environmental impacts and are renewable. Safflower has emerged as a viable alternative to energy because it presents high oil contents reaching 50\% (Silva, 2013). Due to its oleic potential, it can be used as a raw material to produce biofuel thereby reducing dependence on fossil fuels.

In addition to the production of oil it is also used in human consumption and animal feed. According to Augustinho (2013), silage cake is used as an alternative feed for sheep without prejudice to its metabolic functions. Safflower oil presents high levels of linoleic and oleic acids, which are considered of the highest quality for human consumption, presenting lower health risks (Silva, 2013).

However, to better exploit crop potential, deepen studies are required which considers physical and physiological parameters during storage to obtain seeds with vigor and viability, thus expressing their maximum development in the field. According to Cardoso et al. (2012), the seed under goes detoriation process during storage, but knowing its characteristics this deterioration can be delayed.

According to Smaniotto et al. (2013), the temperature and water content in the seed are the major factors affects the seed quality during storage. In addition water content and storage temperature are factors that influence the respiration rate and seed susceptibility to microorganism attack. The temperature interferes with the speed of the biochemical processes that occur in the seeds, their water content, in turn, is controlled by the local air humidity (Goldfarb \& Queiroga, 2013).

The seed is a hygroscopic structure, it performs gas exchanges with the environment until it reaches equilibrium. According to Costa (2015), the sorption isotherm allows to understand the hygroscopic processes that occur with 
the seed during its storage, this in turn, is directly linked to the temperature and pressure during storage. The type of packaging determines the rate of deterioration and, therefore, in the maintenance of the physiological quality of the seeds, packaging that reduces gaseous exchange and water with environment, reduces the metabolic processes ensuring the prolongation and longer longevity of the seeds during storage (Antonelle et al., 2009; Jeromini et al., 2015).

In view of the above, the goal of this research was to evaluate the effects of packaging and storage temperatures on the physical and physiological quality of safflower seed.

\section{Method}

The experiment was carried out in soil and plant production laboratories and in the bromatology laboratory of the Institute of Agrarian and Technological Sciences, Federal University of Mato Grosso, University Campus of Rondonópolis, The experiment was conducted in the soil and plant production and bromatology laboratories of the Institute of Agrarian and Technological Sciences, Federal University of Mato Grosso Campus of Rondonópolis, in the period of July to September 2014. The experimental design was completely randomized in a $5 \times 2$ factorial scheme, corresponding to five temperatures $\left(10,15,20,25,30^{\circ} \mathrm{C}\right)$ and two packages (paper and cotton) with 5 replicates.

Safflower seeds harvested in July 2014, in the municipality of Primavera do Leste-MT, located at latitude $15^{\circ} 33^{\prime}$ $\mathrm{S}$ and longitude $54^{\circ} 17^{\prime} \mathrm{W}$, altitude of $636 \mathrm{~m}$, warm tropical subhumid climate, with annual mean temperature $25^{\circ} \mathrm{C}$ and annual average rainfall of $1804.40 \mathrm{~mm}$.

The seeds were sieved using a set of 4, 2 and $1.18 \mathrm{~mm}$ sieves, by removing impurities and foreign materials. They were then, separated and packed in specific packages according to the specified treatments.

The seed lot used in the experiment had initial values (control sample) of mass in 1000 seeds: $36.28 \mathrm{~g}$, hectolitre weight: $54.8 \mathrm{~kg} \mathrm{hL}^{-1}$, water content (saturation base): $10.39 \%$, electrical conductivity: $127.1 \mu \mathrm{S} \mathrm{cm}^{-1} \mathrm{~g}^{-1}$, percentage of germination: $71.0 \%$, accelerated aging: $54 \%$ and tetrazolium test: $69.2 \%$ of viable seeds.

Two types of package were used to store the seeds: paper and cotton, $1 \mathrm{~mm}$ thick. The dimensions of the packages were $40 \times 20 \mathrm{~cm}$. Each package were placed with $600 \mathrm{~g}$ of seeds, to perform all tests at the end of the storage period, and were maintain stored for 30 days.

The physical and physiological parameters of the seeds were evaluated using the methodology described in the Seed Analysis Rules (MAPA, 2009). The water content in the seed was determined using the forced air circulation oven at $105 \pm 3{ }^{\circ} \mathrm{C}$. The mass of one thousand seeds was performed in eight replicates of 100 seeds.

In the germination test, germitest paper substrate was used. For the evaluation of electrical conductivity, a conductivity meter of the Tecnopon brand, model mCA 150 was used. For the accomplishment of terazolium test, the seeds were immersed in solution of triphenyl chloride of tetrazólio to $1 \%$.

In the evaluation of the accelerated aging, Gerbox plastic boxes were used, with non-galvanized wire sieves containing $40 \mathrm{~mL}$ of distilled water. The set was placed in incubator with controlled temperature at $41{ }^{\circ} \mathrm{C}$, for 48 hours, according to methodology described by Girardi (2013). After the time, the seeds were submitted to moisture and germination test.

The results were submitted to analysis of variance by the F test and the means were compared by the Tukey test, both at $5 \%$ probability, using the SISVAR statistical program (Ferreira, 2008).

\section{Results and Discussion}

There were no significant differences in the variables water content, mass in 1000 seeds and hectolitre weight (Table 1). 
Table 1. Water content, mass of 1000 seeds, hectolitre weight of safflower seeds stored for 30 days in different packages and temperatures

\begin{tabular}{|c|c|c|c|c|c|}
\hline \multirow{2}{*}{ Package } & \multicolumn{5}{|c|}{ Temperature $\left({ }^{\circ} \mathrm{C}\right)$} \\
\hline & 10 & 15 & 20 & 25 & 30 \\
\hline \multicolumn{6}{|c|}{ Water content (\%) } \\
\hline Paper & $8.38 \mathrm{a}$ & $8.48 \mathrm{a}$ & $8.91 \mathrm{a}$ & $8.84 a$ & $8.91 \mathrm{a}$ \\
\hline Cotton & $8.65 \mathrm{a}$ & $9.20 \mathrm{a}$ & $8.89 \mathrm{a}$ & $8.84 a$ & $7.89 \mathrm{a}$ \\
\hline \multicolumn{6}{|c|}{ Mass of 1000 seeds $(\mathrm{g})$} \\
\hline Paper & $36.28 \mathrm{a}$ & $35.87 \mathrm{a}$ & $33.83 \mathrm{a}$ & $35.72 \mathrm{a}$ & $35.75 \mathrm{a}$ \\
\hline Cotton & $34.94 \mathrm{a}$ & $34.53 \mathrm{a}$ & $35.30 \mathrm{a}$ & $33.80 \mathrm{a}$ & $36.60 \mathrm{a}$ \\
\hline \multicolumn{6}{|c|}{ Hectolitre weight $\left(\mathrm{kg} \mathrm{hL}{ }^{-r}\right)$} \\
\hline Paper & $56.30 \mathrm{a}$ & $58.20 \mathrm{a}$ & $58.20 \mathrm{a}$ & $58.00 \mathrm{a}$ & $57.30 \mathrm{a}$ \\
\hline Cotton & $58.30 \mathrm{a}$ & $57.50 \mathrm{a}$ & $58.50 \mathrm{a}$ & $58.40 \mathrm{a}$ & $57.80 \mathrm{a}$ \\
\hline
\end{tabular}

Note. The averages followed by the same letter, vertically, do not differ statistically from each other by the Tukey test, at $5 \%$ probability.

The electrical conductivity was influenced by the packages at different storage temperatures. The temperature of $20{ }^{\circ} \mathrm{C}$ in paper package provided a lower conductivity value of $130.50 \mu \mathrm{S} \mathrm{cm}^{-1} \mathrm{~g}^{-1}$, while at temperatures of 10 and $30{ }^{\circ} \mathrm{C}$ the lowest values for electrical conductivity were 140.20 and $136.00 \mu \mathrm{S} \mathrm{cm}^{-1} \mathrm{~g}^{-1}$ respectively, observed in cotton package (Table 2).

Table 2. Electric conductivity, percentage of germination, tetrazolium test, accelerated aging and seedling length of safflower seeds stored for 30 days in different packages and temperatures

\begin{tabular}{|c|c|c|c|c|c|}
\hline \multirow{2}{*}{ Package } & \multicolumn{5}{|c|}{ Temperature $\left({ }^{\circ} \mathrm{C}\right)$} \\
\hline & 10 & 15 & 20 & 25 & 30 \\
\hline \multicolumn{6}{|c|}{ Electric conductivity $\left(\mu \mathrm{Scm}^{-1} \mathrm{~g}^{-1}\right)$} \\
\hline Paper & $144.20 \mathrm{a}$ & $134.20 \mathrm{a}$ & $130.50 \mathrm{~b}$ & $133.1 \mathrm{a}$ & $141.40 \mathrm{c}$ \\
\hline Cotton & $140.20 \mathrm{~b}$ & $136.70 \mathrm{a}$ & $134.80 \mathrm{a}$ & $132.3 \mathrm{a}$ & $136.00 \mathrm{~b}$ \\
\hline$C V(\%)$ & 2.24 & & & & \\
\hline \multicolumn{6}{|c|}{ Percentage of germination $(\%)$} \\
\hline Paper & $44.80 \mathrm{a}$ & $54.80 \mathrm{a}$ & $65.20 \mathrm{a}$ & $57.20 \mathrm{a}$ & $50.00 \mathrm{a}$ \\
\hline Cotton & $43.20 \mathrm{a}$ & $47.60 \mathrm{~b}$ & $51.20 \mathrm{~b}$ & $54.40 \mathrm{a}$ & $47.60 \mathrm{a}$ \\
\hline$C V(\%)$ & 9.64 & & & & \\
\hline \multicolumn{6}{|c|}{ Tetrazolium test (\%) } \\
\hline Paper & $51.80 \mathrm{a}$ & $46.60 \mathrm{a}$ & $58.80 \mathrm{a}$ & $58.00 \mathrm{a}$ & $47.40 \mathrm{a}$ \\
\hline Cotton & $45.60 \mathrm{a}$ & $44.00 \mathrm{a}$ & $52.00 \mathrm{a}$ & $55.60 \mathrm{a}$ & $39.40 \mathrm{a}$ \\
\hline$C V(\%)$ & 8.21 & & & & \\
\hline \multicolumn{6}{|c|}{ Accelerated aging $(\%)$} \\
\hline Paper & $35.60 \mathrm{a}$ & $44.80 \mathrm{a}$ & $50.40 \mathrm{a}$ & $51.60 \mathrm{a}$ & $43.60 \mathrm{a}$ \\
\hline Cotton & $36.80 \mathrm{a}$ & $37.20 \mathrm{a}$ & $38.40 \mathrm{a}$ & $39.20 \mathrm{a}$ & $36.80 \mathrm{a}$ \\
\hline$C V(\%)$ & 11.86 & & & & \\
\hline \multicolumn{6}{|c|}{ Seedling length-7days $(\mathrm{cm})$} \\
\hline Paper & $2.20 \mathrm{a}$ & $2.20 \mathrm{a}$ & $3.80 \mathrm{a}$ & $2.60 \mathrm{a}$ & $2.00 \mathrm{a}$ \\
\hline Cotton & $2.40 \mathrm{a}$ & $2.20 \mathrm{a}$ & $3.80 \mathrm{a}$ & $2.20 \mathrm{a}$ & $2.40 \mathrm{a}$ \\
\hline$C V(\%)$ & 21.58 & & & & \\
\hline \multicolumn{6}{|c|}{ Seedling length-14 days $(\mathrm{cm})$} \\
\hline Paper & $5.00 \mathrm{a}$ & $5.20 \mathrm{a}$ & $7.00 \mathrm{a}$ & $9.20 \mathrm{a}$ & $6.60 \mathrm{a}$ \\
\hline Cotton & $5.00 \mathrm{a}$ & $5.40 \mathrm{a}$ & $6.80 \mathrm{a}$ & $8.00 \mathrm{a}$ & $6.00 \mathrm{a}$ \\
\hline$C V(\%)$ & 17.20 & & & & \\
\hline
\end{tabular}

Note. The averages followed by the same letter, vertically, do not differ statistically from each other by the Tukey test, at $5 \%$ probability. 
According to Baudet (2003) both cotton and paper packages are considered permeable. This type of packaging allows the occurrence of water vapor exchanges between the internal and external environment until reaching hygroscopic equilibrium. The increase in temperature leads to decomposition of the lipid molecules present in the seed and consequent increase in the deterioration rate (Marcos Filho, 2005). This process can be observed in both packages, where the increase in temperature from $10{ }^{\circ} \mathrm{C}$ caused an increase in the electric conductivity of the seeds.

Setting the temperature to study the types of packages it was verified the influence of these in the temperatures of 15 and $20{ }^{\circ} \mathrm{C}$ where the greater percentage of germination was observed in the paper packaging. In the tetrazolium test, it was observed that the seeds stored between the temperatures of 20 and $25{ }^{\circ} \mathrm{C}$ stored in paper packaging presented greater vigor and viability in the reaction with the tetrazolium solution. Similar results were found when the seeds undergoing accelerated aging process.

Regarding the length of the seedling, no significant difference was observed in the seeds stored at the different temperatures in both packages.

For the water content in the seed there was no significant difference using paper packaging at different temperatures. For cotton packaging there was a significant difference at $5 \%$ probability at different temperatures, adjusting to the quadratic regression model. The temperature of $17.61{ }^{\circ} \mathrm{C}$ with cotton packaging provided less loss of the water content of the safflower seeds, corresponding to $9.13 \%$. Possibly this effect is due to the exchange of water vapor of the seed with the environment, since they were stored at different temperatures and respiratory activity (Figure 1).

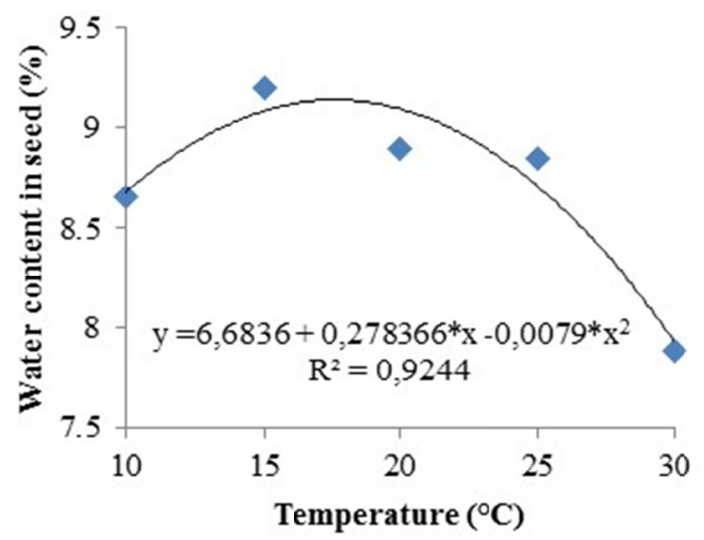

Figure 1. Water content in safflower seed stored for 30 days at different temperatures and cotton packaging. * Significant at $5 \%$ probability

According to Smaniotto et al. (2013), the increase in temperature causes an increase in respiratory rate causing the seed to lose part of its water to the environment until it reaches equilibrium. This loss was more pronounced in the environment where the seeds were stored at a temperature of $30^{\circ} \mathrm{C}$, where the water content in the seeds before storage was $10.39 \%$, decreasing to $7.89 \%$ in the cotton package. These results corroborate with those found by Paraginski et al. (2015), who working with storage of maize seed at different storage temperatures also observed a decrease in water content with increasing temperature.

Regarding the electrical conductivity of the seed, the temperature of $20.53{ }^{\circ} \mathrm{C}$ provided lower deterioration of seeds in paper package and $23.21{ }^{\circ} \mathrm{C}$ in the cotton package with conductivity of 130.85 and $133.71 \mu \mathrm{S} \mathrm{cm}^{-1} \mathrm{~g}^{-1}$, respectively. In both cases, a decrease in the conductivity value of the safflower seed was observed between temperatures of approximately 10 to $20^{\circ} \mathrm{C}$. Thereafter, there was an increase in the electrical conductivity of the seed (Figure 2). 


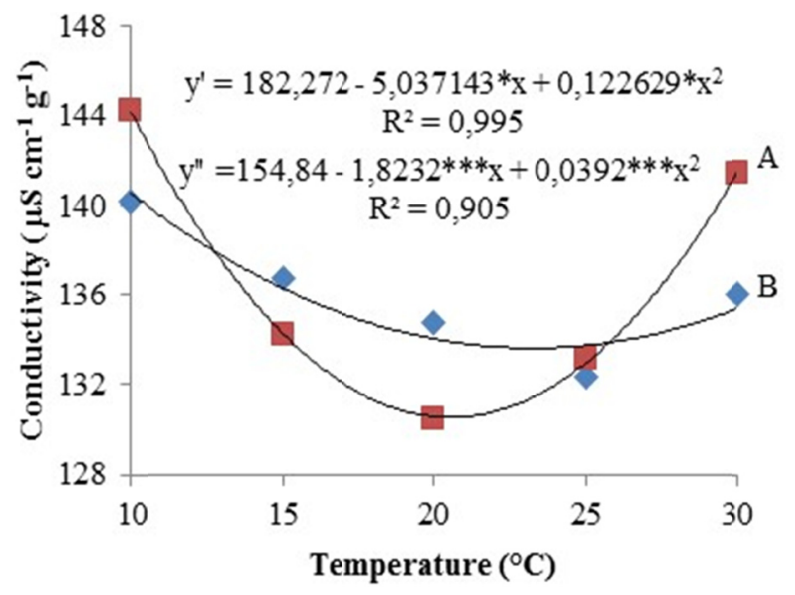

Figure 2. Electric conductivity of safflower seeds stored in paper package (A) and cotton package (B). *, *** Significant at 5 and $0.1 \%$ probability, respectively

The results of the present study corroborate those found by Paraginski et al. (2015), who worked with corn seed storage at different temperatures, observed an increase in the electric conductivity of the seed with increasing temperature.

The electrical conductivity value of the seed reflects its degree of degradation of the cell membrane and consequent deterioration of the seed. The lowest values correspond to the low degree of deterioration and, consequently, high physiological potential of the seed. Abreu et al. (2011) working with sunflower seeds stored at different temperatures for a period of 6 months did not observe significant differences in seed conductivity, but the authors report that there was a fall in the physiological attribute through the germination test when stored at low temperatures.

Fessel et al. (2010) observed that soybean seeds stored at a temperature of $10{ }^{\circ} \mathrm{C}$ showed maintenance of the membrane integrity and, consequently, lower release of leachate during the immersion in solution made during the electrical conductivity test.

The percentage of germination of the seeds stored under different temperature and packaging conditions presented a significant difference adjusting to the quadratic regression model. Using paper package in the safflower seed storage, the highest percentage (62.24\%) of germinated seeds was observed at the temperature of $20.83{ }^{\circ} \mathrm{C}$. The temperature of $22.39^{\circ} \mathrm{C}$ provided a higher percentage of seed germination $(52.43 \%)$ in the cotton package (Figure 3).

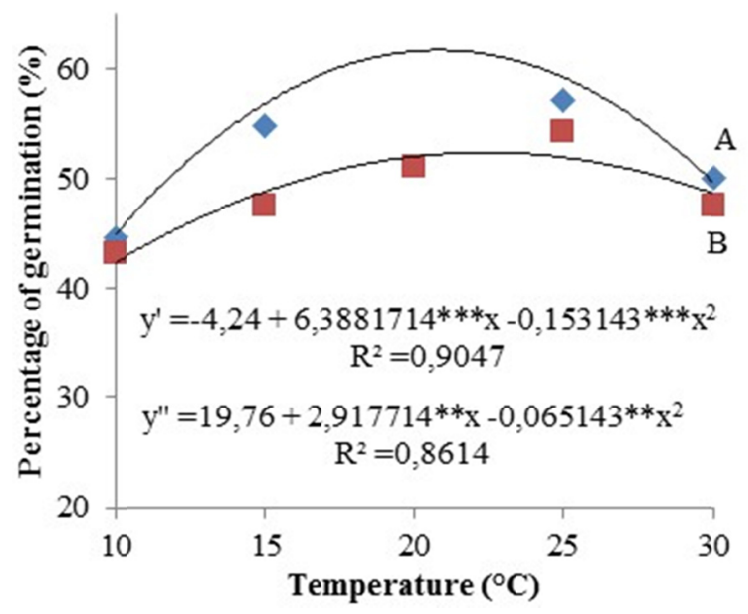

Figure 3. Percentage of germination of safflower seeds stored in paper (A) and cotton (B) packages under different temperature conditions. ${ }^{* *}, * * *$ Significant at 1 and $0.1 \%$ probability, respectively 
These results are related with the cell membrane structure of the seed has been undone by observing the electrical conductivity test during storage. Demuner et al. (2008) working with mulungu seeds observed that the temperature of $20^{\circ} \mathrm{C}$ provided greater germination.

According to Pascuali et al. (2012) temperature elevation favors increased seed respiration activity, accelerating its deterioration process during storage. Many proteins were degraded due to the increase in storage temperature that caused alteration in the permeability of cells plasma membranes and, consequently, loss of cellular content to the external environment and drop in viability and vigor.

With respect to the tetrazolium test, there was an isolated effect of the temperature adjusting to the quadratic regression model in both packages, where temperatures of 19.91 and $20.38{ }^{\circ} \mathrm{C}$ provided 52.14 and $55.92 \%$ of healthy seeds through of the tetrazolium salt stored in cotton and paper packaging, respectively (Figure 4).

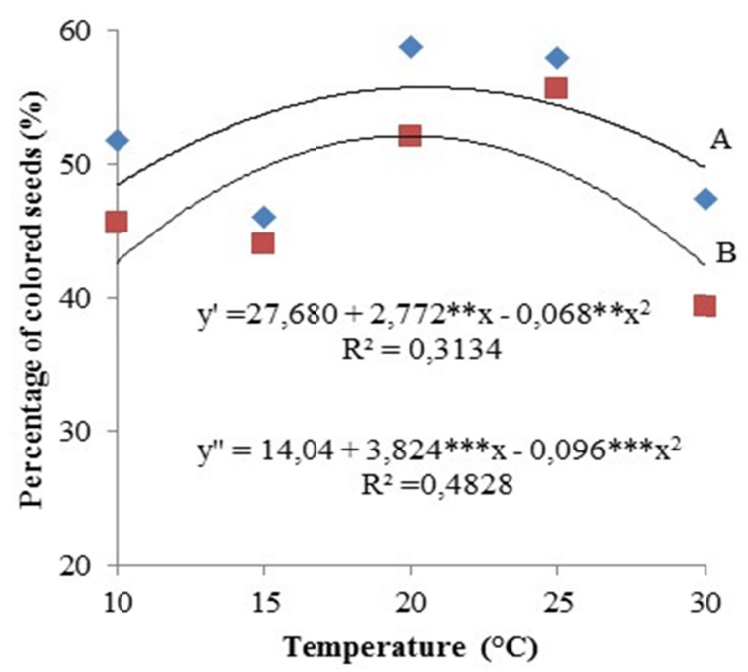

Figure 4. Percentages of safflower seeds colored by immersion in $1 \%$ Tetrazolium solution, stored in paper (A) and cotton (B) packages. ${ }^{* *},{ }^{* *}$ Significant at 1 and $0.1 \%$ probability, respectively

The tetrazolium test is based on the verification of the respiratory activity of the seed, when immersed in tetrazolium solution there is formation of a red compound, triphenylformazan, indicating the presence of live cells (Lazarotto et al., 2011). Compared with other tests the tetrazolium test presents fast results for possible making decision.

The seed staining pattern during the tetrazolium test ranged from red, viable seeds, and white, non-viable seeds, indicating the reaction of the tetrazolium salt with the hydrogen ions released by the respiratory process. It was observed that temperatures of 20 and $25^{\circ} \mathrm{C}$ there was a greater quantity of seeds that were colored (values above $50 \%$ ) and at temperature of $30^{\circ} \mathrm{C}$ there was less quantity of seeds that were colored.

The results observed in the tetrazolium test were similar to those of the germination test, which proves its efficacy for the safflower seed. The result of this test allowed identify the vigor and viability of the seeds.

The results obtained in the tetrazolium tests corroborate with those found by Marini et al. (2012) observations on the rice seed germination, where temperatures of 15 and $35^{\circ} \mathrm{C}$ exhibited lower seed vigor and temperatures between 20 to $25^{\circ} \mathrm{C}$, greater vigor.

Another fact observed in the physiological quality conservation is the characteristic of the seed used in the experiment. Safflower is considered an oleaginous plant and, therefore, the loss of water during its storage is greater (Puzzi, 2000). Possibly the increase in storage temperature from $20{ }^{\circ} \mathrm{C}$ to $30{ }^{\circ} \mathrm{C}$ increased the loss of water by the seed accelerating the deterioration process and, consequently, death of the cellular tissues present in the seed.

At all temperatures that the safflower seeds were submitted at the storage process, the paper package afforded a higher percentage of seeds that reacted with the tetrazolium solution. 
In the analysis of the germination of seeds submitted to accelerate aging, there was interaction between temperature and storage factors. The temperature of $22.10^{\circ} \mathrm{C}$ provided a higher percentage of germinated seeds $(55.03 \%)$, stored in paper package after submission to accelerated aging (Figure 5).

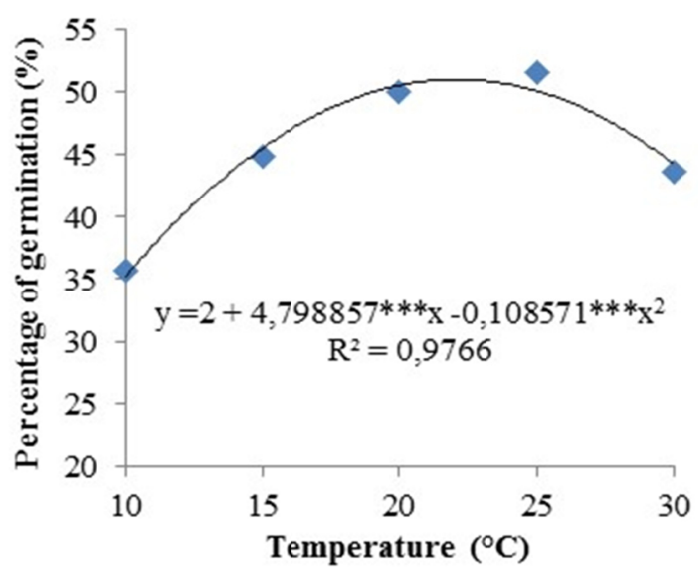

Figure 5. Percentage of germination of safflower seeds subjected to the accelerated aging test, stored in paper package at different temperatures. ${ }^{* * *}$ Significant at $0.1 \%$

These results allow us to affirm that temperature is one of the fundamental factors for the storage and conservation of seeds because when stored at an ideal temperature it is possible to minimize the effects while preserving their physiological quality.

For seedling length, there was a significant interaction of temperature with respect to the packaging, adjusting to the quadratic regression model. Temperatures of 20.02 and $19.99{ }^{\circ} \mathrm{C}$ provided the highest seedling lengths (2.94 and $3.13 \mathrm{~cm}$ ) in the paper and cotton packages, respectively, at seven days. At fourteen days, temperatures of 24.84 and $23.21{ }^{\circ} \mathrm{C}$ provided higher seedling length $(7.69$ and $7.10 \mathrm{~cm})$ in paper and cotton packages, respectively (Figure 6).
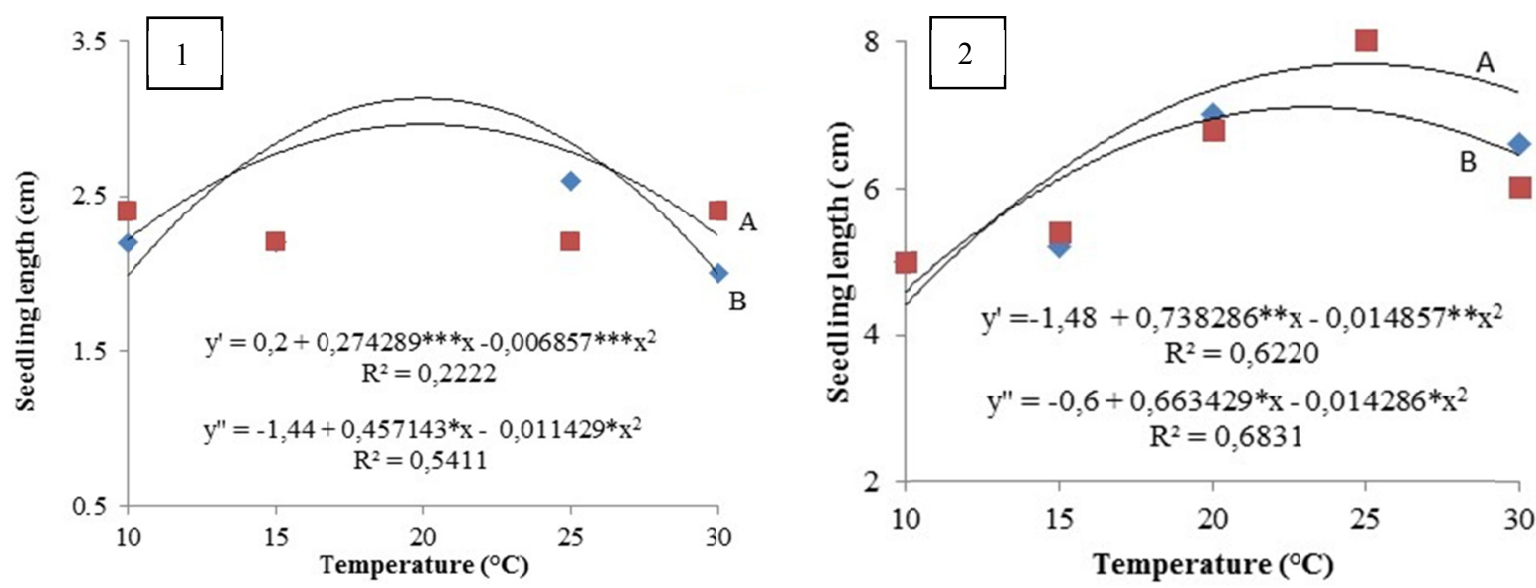

Figure 6. Seedling length of safflower under the conditions of storage temperatures in paper package (A) and cotton package (B) at (1) 7 days and (2) 14 days. *,**,*** Significant at 5, 1 and $0.1 \%$, respectively

Beltrame et al. (2013), conducting a study of the germination speed of the seeds of Ateleia glazioveana Baill, found that temperatures between 20 and $25^{\circ} \mathrm{C}$ provided higher seedling length.

During the seed germination process there is a sequence of physiological events and ideal temperature conditions are essential for the occurrence of these events (Carvalho \& Nakagawa, 2012). The temperature interferes with the percentage directly, speed of germination and imbibition, and biochemical reactions occurring in seed tissues, 
mobilizing and degrading accumulated nutritional reserves necessary for seedling development and growth (Bewley \& Black, 1994).

\section{Conclusions}

Temperatures between 20 and $25{ }^{\circ} \mathrm{C}$ provided greater conservation of the physical and physiological attributes of safflower seeds, packaged in paper package.

\section{References}

Abreu, L. A. S. (2011). Teste de condutividade elétrica na avaliação de sementes de girassol armazenadas sob diferentes temperaturas. Revista Brasileira de Sementes, 33, 637-644.

Antonello, L. M., Muniz, M. B., Brand, S. C., Vidal, M. D., Garcia, D., Ribeiro, L., \& Santos, V. (2009). Qualidade de sementes de milho armazenadas em diferentes embalagens. Ciência Rural, 39, 2191-2194. https://doi.org/10.1590/S0103-84782009005000157

Augustinho, E.T. (2013). Silagem e torta de cártamo na alimentação de ovinos como alternativa à silagem de milho e farelo de soja (88f., Dissertação de Mestrado, Instituto de Zootecnia, APTA/SAA, Nona Odessa, $\mathrm{SP})$.

Baudet, L. M. L. (2003). Armazenamento de sementes. In S. T. Peske, M. D. Rosental, \& G. R. Rota (Eds.), Fundamentos cientificos e tecnológicos (pp. 370-418). Universitária-UFPel, Pelotas, Brazil.

Beltrame, R. A., Lopes, J. C., Paulúcio, M. C., Carlo, S. E. C. P., \& Manhone, P. R. (2013). Germinação de sementes e desenvolvimento de plântulas de Ateleia glazioveana Baill em diferentes temperaturas. Enciclopédia Biosfera, 9(17), 33.

Bewley, J. D., \& Black, M. S. (1994). Physiology of development and germination (p. 445). Plenum Press, New York, USA.

Cardoso, R. B., Binotti, F. F. S., \& Cardoso, E. D. (2012). Potencial fisiológico de sementes de crambe em função de embalagens e armazenamento. Pesquisa Agropecuária Tropical, 42, 272-278. https://doi.org/ $10.1590 /$ S1983-40632012000300006

Carvalho, N. M., \& Nakagawa, J. (2012). Sementes: Ciência tecnologia e produção (p. 590). FUNEP, Jaboticabal, Brazil.

Costa, L. M., Resende, O., Oliveira, D. E. C., \& Souza, K. A. (2015). Isotermas e calor isostérico de sementes de Buchenavia capitata (Vahl) Eichler. Revista Ciência Agronômica, 46, 516-523. https://doi.org/10.5935/ 1806-6690.20150033

Demuner, V. G., Adami, C., Mauri, J., Dalcomo, S., \& Hebling, S. A. (2008). Influência da luz e da temperatura na germinação de sementes de Erythrina verna (Leguminosae-Papilionoideae). Boletim do Museu de Biologia Mello Leitão, 24, 101-110.

Ferreira, D. F. (2008). SISVAR: Um programa para análises e ensino de estatística. Revista Symposium, 6, 36-41.

Fessel, S. A., Panobianco, M., Souza, C. R., \& Vieira, R. D. (2010). Teste de condutividade elétrica em sementes de soja armazenadas sob diferentes temperaturas. Bragantia, 69, 207-214. https://doi.org/10.1590/ S0006-87052010000100026

Girardi, L. B, Lazarotto, M., Dorigon, M. R., Pedroso, D. C., Müller, J., \& Muniz, M. F. B. (2013). Envelhecimento acelerado em sementes de Cártamo. Revista FZVA, 19, 43-54.

Goldfarb, M., \& Queiroga, V. De P. (2013). Considerações sobre o armazenamento de sementes. Tecnologia e Ciência Agropecuária, 7, 71-74.

Jeromini, T. S., Scalon, S. P., Pereira, S. T. S., Franchinelli, R., \& Filho, H. S. (2015). Armazenamento de sementes e sombreamento na emergência e crescimento inicial das mudas de Magonia pubescens a. st.-hil. Revista Árvore, 39, 683-690. https://doi.org/10.1590/0100-67622015000400010

Lazarotto, M., Piveta, G., \& Muniz, M. F. B. (2011). Adequação do teste de tetrazólio para avaliação da qualidade de sementes de Ceiba speciosa. Ciências Agrárias, 32, 1243-1250. https://doi.org/10.5433/ 1679-0359.2011v32n4p1243

MAPA (Ministério da Agricultura e Reforma Agrária). (2009). Regras para análise de sementes (p. 399). Brasília, Brazil.

Marcos, F. J. (2005). Fisiologia de sementes de plantas cultivadas (p. 495). FEALQ, Piracicaba, Brazil. 
Marini, P., Moraes, C. L., Marini, N., Moraes, D. M., \& Amarante, L. (2012). Alterações fisiológicas e bioquímicas em sementes de arroz submetidas ao estresse térmico. Revista Ciência Agronômica, 43, 722-730. https://doi.org/10.1590/S1806-66902012000400014

Paraginski, R. T., Rockenbach, B. A., Santos, R. F., Elias, M. C., \& Oliveira, M. (2015). Qualidade de grãos de milho armazenados em diferentes temperaturas. Revista Brasileira de Engenharia Agrícola Ambiental, 19, 358-363. https://doi.org/10.1590/1807-1929/agriambi.v19n4p358-363

Pascuali, L. C., Silva. F. S., Porto, A. G., Filho, A. S., \& Meneghello, G. E. (2012). Germinação de sementes de pinhão manso em diferentes temperaturas, luz e substratos. Ciências Agrária, 33, 1435-1440. https://doi.org/10.5433/1679-0359.2012v33n4p1435

Puzzi, D. (2000). Abastecimento e armazenamento de grãos (p. 666). Instituto campineiro de ensino Agrícola, Campinas, Brazil.

Silva, C. J. (2013). Caracterização agronômica e divergência genética de acessos de cártamo (76f., Tese de Doutorado, Faculdade de Ciências Agronômica, Botucatu, Brazil).

Smaniotto, J. R. (2013). Contribuição de bactérias endofiticas no crescimento e nutrição de genotipos de arroz de sequeiro (67f., Dissertação de mestrado, Universidade do Estado Santa Catarina, Lages, Brazil).

\section{Copyrights}

Copyright for this article is retained by the author(s), with first publication rights granted to the journal.

This is an open-access article distributed under the terms and conditions of the Creative Commons Attribution license (http://creativecommons.org/licenses/by/4.0/). 